\title{
Notes on the vocalizations of Fawn-breasted Waxbill (Estrilda paludicola)
}

\section{Peter Boesman}

In the following we briefly analyze and compare voice of the different races of Fawn-breasted Waxbill (Estrilda paludicola). We also try to quantify the extent of any vocal differences using the criteria proposed by Tobias et al. (2010), as a support for taxonomic review.

We have made use of sound recordings available on-line from Xeno Canto (XC) and Macaulay Library (ML).

There are only a handful recordings available:
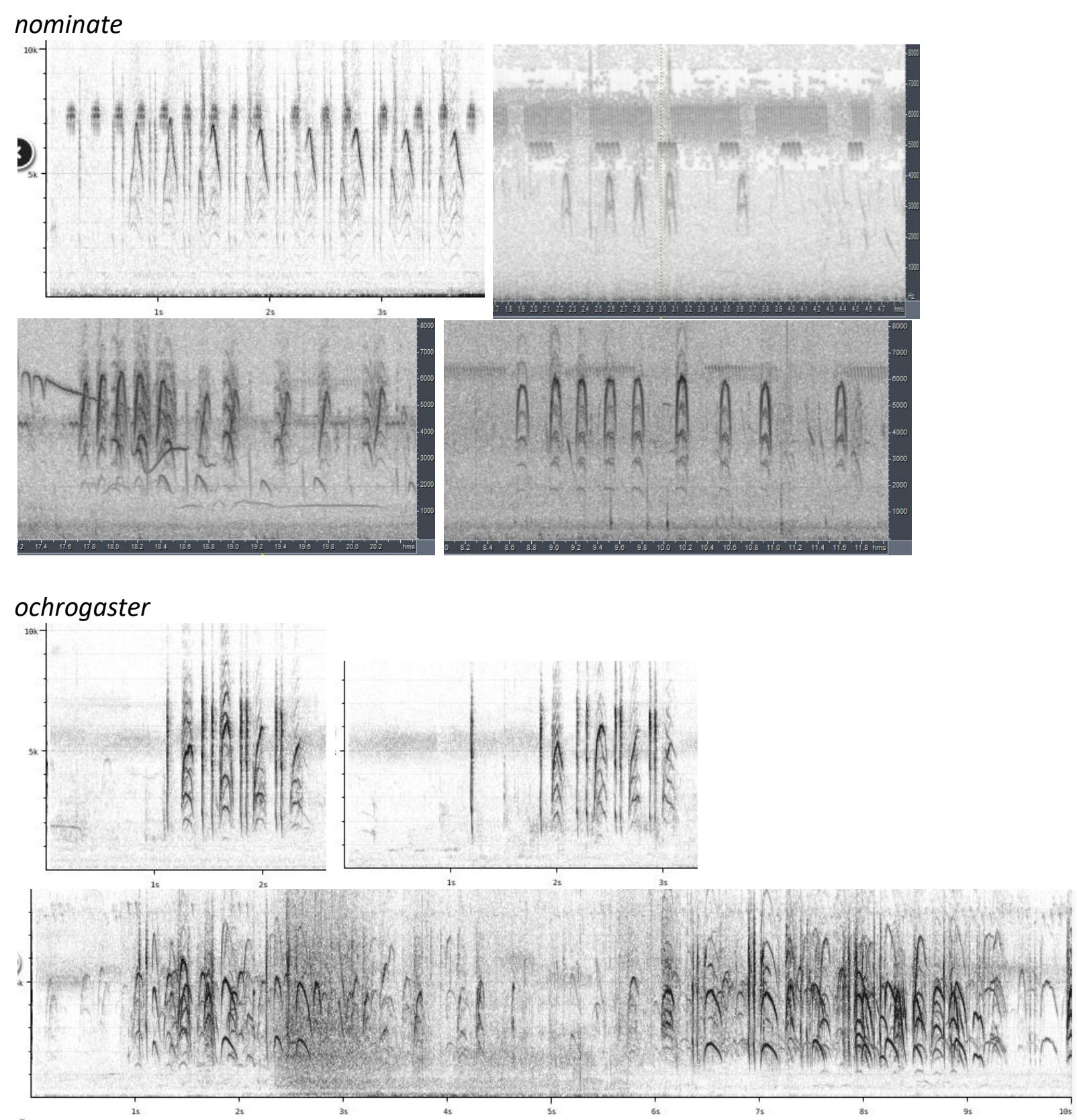

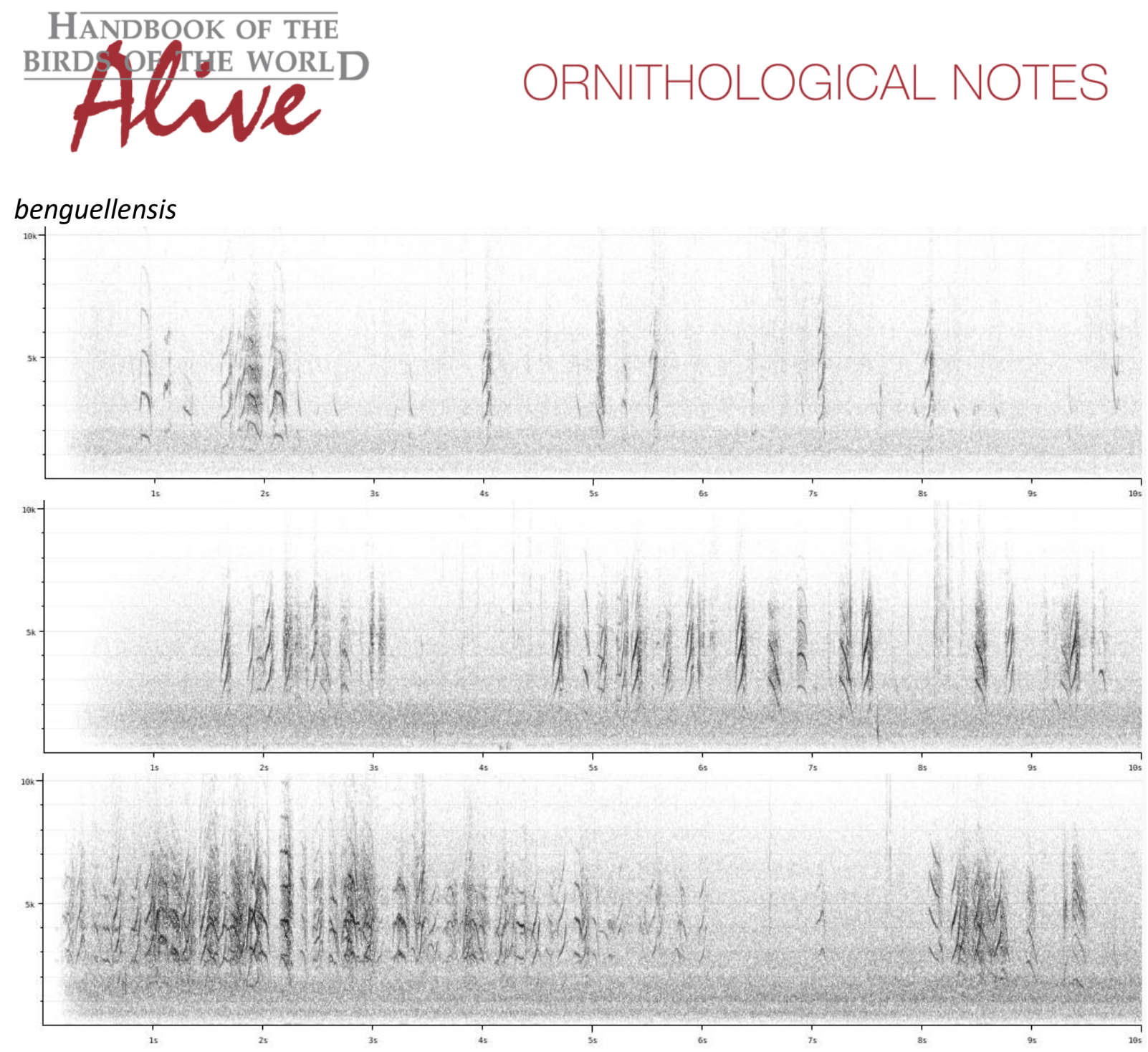

Song seems to be one or two very short notes followed by a nasal overslurred note, having quite a rhythmic cadence. Calls are just the nasal notes.

ochrogaster very similar to nominate. Nasal note of nominate apparently slightly higherpitched, with most of the energy above $3 \mathrm{kHz}$, while ochrogaster has also clear amplitude in the $2-3 \mathrm{kHz}$ range. This vocal difference could be scored $1-2$.

benguellensis seems to be more different, with many notes either upslurred or downslurred, none of which is found in recordings of the above two races. A tentative score of at least 2 seems appropriate here to reflect the more important vocal difference.

There are clearly some vocal differences among the various races, but more recordings are needed to get a better understanding of these.

This note was finalized on 28th April 2016, using sound recordings available on-line at that moment (and updated on 26th October 2016, with new recordings of race benguellensis). We would like to thank in particular the sound recordists who placed their recordings for this species on XC and ML: Peter Boesman, Marcell Claassen, Peter Kaestner, Rory Nefdt, jelmer Poelstra and Andrew Spencer. 


\section{References}

Tobias, J.A., Seddon, N., Spottiswoode, C.N., Pilgrim, J.D., Fishpool, L.D.C. \& Collar, N.J. (2010). Quantitative criteria for species delimitation. Ibis 152(4): 724-746.

\section{Recommended citation}

Boesman, P. (2016). Notes on the vocalizations of Fawn-breasted Waxbill (Estrilda paludicola). HBW Alive Ornithological Note 346. In: Handbook of the Birds of the World Alive. Lynx Edicions, Barcelona. (retrieved from http://www.hbw.com/node/1252873 on 26 October 2016). 